\title{
ENTREPRENEURS' LEARNING PREFERENCES: A GUIDE FOR ENTREPRENEURSHIP EDUCATION
}

\author{
C Nieuwenhuizen \& D Groenewald, Faculty of Management, University of Johannesburg, South Africa
}

\begin{abstract}
Purpose: The purpose of the paper is to determine guidelines for effective entrepreneurship education and training, focussing on the development of entrepreneurial skills, based on what successful, established entrepreneurs look like, how they operate and their learning and thinking preferences.
\end{abstract}

Problem investigated: Entrepreneurial skills training is the difficult part of teaching entrepreneurship and is different from teaching functional and managerial skills related to entrepreneurship. The problem is that training and education focuses primarily on the management and functional business training of entrepreneurs and very seldom on the entrepreneurial skills. This study focuses on the much neglected second leg of entrepreneurship training, as most entrepreneurship programmes focus on the first leg, namely business planning and functions and management skills.

Design/methodology/approach: This is a formal and exploratory study. Two measurement instruments (Schein Career Orientations Inventory and the Neethling Brain Instrument) were used and completed by a sample of 50 entrepreneurs of the identified population. The paper address the entrepreneurship education needs as determined by the learning preferences of entrepreneurs.

Findings: The research indicated that all the essential entrepreneurial skills are seldom addressed in entrepreneurial training. The entrepreneurial skills that need to be incorporated in these programmes are self-concept, creativity and innovation, risk orientation, good human relations; perseverance and a positive attitude. The research also revealed that entrepreneurs have different learning preferences from other students/learners and this should be taken into consideration in the design of entrepreneurial curricula.

Value of research: The paper assist curriculum developers of entrepreneurship education programmes to better align their content to the entrepreneurial skills identified by successful entrepreneurs that need to be developed, and to conduct entrepreneurship education according to the learning preferences of entrepreneurs.

Conclusion: The application of the Garavan and O'Cinneide model regarding the methodology in the education of entrepreneurs can therefore be confirmed and recommended. The results of the career anchor and brain instruments indicate the importance of entrepreneurial skills-training and include training in the following areas: self concept; creativity and innovation; risk orientation; good human relations, perseverance and positive attitude.

Key words and phrases: entrepreneurs; entrepreneurship, entrepreneurial skills, education, training learning preferences.

\section{INTRODUCTION}

In the current South African economy it is estimated that more than 8 million people will be unemployed in South Africa (SA) by 2010 (Gouws, 1997:143 in Co and Mithcell, 2006:348). For young people to be accommodated in the economy they will have to be trained and educated in the field of entrepreneurship. This will hopefully encourage them to become job-creators instead of job-seekers once they leave the educational system.

Entrepreneurial behaviour has become more common, calling for better entrepreneurial skills and abilities when dealing with current challenges and an uncertain future. Henry, Hill and Leitch (2004:99) indicates that an innovative approach to problem solving, high readiness for change, selfconfidence and creativity - all attributes related to entrepreneurship - constitute a viable platform for economic development in any society. Therefore it has been maintained that the need for entrepreneurship education has never been greater, and the opportunities have never been so abundant.

In this paper the problem statement are outlined followed by the research objectives of this study. In the literature review the importance and need for entrepreneurial education and training as well as the education and training methods for entrepreneurs are addressed. Following the literature review the 
importance of the study and the research methodology are stated. Lastly an in depth discussion of the results of the study and the conclusion and recommendations are given.

\section{PROBLEM STATEMENT}

Entrepreneurial skills training is the difficult part of teaching entrepreneurship and is different from teaching functional and managerial skills related to entrepreneurship. In South Africa the Total Entrepreneurial Activity (TEA) as measured by the Global Entrepreneurship Monitor (Orford, Herrington and Wood, 2004:3) was $5.4 \%$ as opposed to the average of $9.4 \%$ in all 34 countries included in the 2004 survey and $21 \%$ in the developing countries included in the 2004 survey. The South African TEA rate is in line with that of Poland, Hungary and Croatia, countries that were also suppressed by legal and political systems rendering it illegal in socialist countries, as it was for blacks under the apartheid system. The implication is that these systems have a long term effect on the attitudes, skills and economic structures of these countries and this explains the lower than expected TEA rates. The expectation is that SA should have a TEA rate of at least $15 \%$. (Orford et al., 2004:11). An additional reason for the low TEA in SA is the low survival rate of start-ups, meaning firms that have not paid wages and salaries for more than three months, and actually become new firms, that is businesses that survived the initial start-up period and are between three months and three-and-a-half years in existence. This is a matter of concern as start-ups do not actually contribute to economic development employing less than one person on average, as opposed to new firms that employ on average 2.5 people per firm (Orford, et al., 2004:13). These facts underscore the importance of developing and assisting individuals with entrepreneurial potential to ensure increased survival of start-up and new enterprises and the establishment of higher levels of successful enterprises.

It is thus clear that a strong need for a more focussed approach on the development of entrepreneurial skills and traits exists. This includes traits and skills such as creativity and innovation, risk propensity and need for achievement.

Entrepreneurship education and training can be seen as standing on two legs, namely:

1. business planning and functions and management skills; and

2. entrepreneurial skills and traits including background and experience carried over to the entrepreneur by parents and educators.

The problem is that training and education focuses primarily on the management and functional business training of entrepreneurs and very seldom on the entrepreneurial skills. This study focuses on the much neglected second leg of entrepreneurship training, as most entrepreneurship programmes focus on the first leg, namely business planning and functions and management skills.

The management question addressed in this research is: what guidelines can be formulated for entrepreneurship education, determined by their learning preferences that will focus on the development of entrepreneurial skills?

In this regard the research questions to be answered by this study to support the management question are: firstly to explore the importance and need for entrepreneurial education, what education methods are used for entrepreneurs, and what the learning preferences of entrepreneurs are. Secondly, it investigates which important entrepreneurial skills successful entrepreneurs require and in which entrepreneurial skills entrepreneurs must be educated.

\section{RESEARCH OBJECTIVES}

The primary objective of this research is to determine guidelines for effective entrepreneurship education and training, focussing on the development of entrepreneurial skills, based on what successful, established entrepreneurs look like, how they operate and their learning and thinking preferences. 
In order to achieve this primary objective the following secondary objectives are formulated. The secondary objectives are:

1. to determine what successful, established entrepreneurs look like; and

2. to identify guidelines for effective development of entrepreneurial skills through education.

With the problem statement and the research objectives clarified a literature review on the need for entrepreneurial education and training as well as various education and training methods for entrepreneurs are reviewed next.

\section{LITERATURE REVIEW}

In the literature review the importance and need for entrepreneurial education and training as well as various education and training methods for entrepreneurs are reviewed.

\section{The Importance and Need for Entrepreneurial Education and Training}

Research conducted by Ibrahim and Soufani (2002:422) and Owusu-Ansah and Fleming (2002:91) revealed that entrepreneurs who attended entrepreneurship courses have a high tendency to start their own businesses compared with those attending other business courses or not attending any courses. These researchers also confirmed research that indicated that entrepreneurship training is critical to venture success.

According to Ladzani and Van Vuuren (2002:158) training plays a pivotal role in supporting small businesses. Ladzani and Van Vuuren recommended that entrepreneurship training should be seen as one of the basic requirements of starting and managing a business. Educational Institutions should introduce and/or strengthen entrepreneurship education. An entrepreneurial culture should begin at home, and then proceed to higher education and training institutions.

The research studies of Ibrahim and Soufani (2002:427) revealed that most entrepreneurial traits can be predicted in individuals' early in life. The ability to predict entrepreneurial traits draws attention to the significant role of entrepreneurship training and development in pre and early adulthood. Prediction also draws attention to the significant role of the family, the education system and the government and non-government organisations that have a vested interest in developing a strong small-business sector that is capable of competing effectively world-wide.

Sullivan (2000:168) revealed in the study conducted on entrepreneurial learning and mentoring that, entrepreneurs believe that the underpinning knowledge gained in taking part in theoretical management courses has been critical when faced with "real life" incidents and is of the view that this enabled them to reflect on the incidents and intellectualise any learning that took place. This means that the ability to dissect, reflect, learn and act on a critical incident was seen to be of great importance.

Henry, Hill and Leitch (2005:101) indicate that through the study of entrepreneurship, entrepreneurs will be able to benefit from learning an innovative approach to problem solving; adapt more readily to change; become more self-reliant and develop their creativity.

According to Orford et al. (2004:4) South Africa ranks in the lowest quartile of all the developing countries with only five out of every hundred adults being an entrepreneur. One of the key factors in changing the status quo is education. In South Africa there are too few people with entrepreneurial qualities, leading to a situation where the South African economy underperforms because only a very limited number of people succeed as entrepreneurs.

\section{Education and Training Methods for Entrepreneurs}

Nieman (2001:446) indicated that entrepreneurship and small enterprise training can be approached from different angles. The main areas of concentration are business skills training, technical skills training and entrepreneurial skills training. Business skills' training covers all conventional 
management training areas in a business. Technical skills training aims to address the ability to use knowledge or techniques of a particular discipline to attain certain ends. Entrepreneurial training involves the establishment and growth of business enterprises and includes, among other entrepreneurial traits, creativity and innovation, risk propensity and need for achievement. Ladzani (1999:70) found that training interventions in South Africa aimed at personal motivation and entrepreneurial skills, are still rather the exception than the rule.

In the education and training of entrepreneurs the understanding of the learning process relating to entrepreneurs is of great importance (Sullivan, 2000:161). Sullivan (2000:162) indicates how learning can be supported in the context of start-up businesses or entrepreneurs. Sullivan suggests mentoring to conduct this training. More specific mentoring is seen as a means of supporting start-up entrepreneurs through the provision of "expert" help and assistance in overcoming problems.

Harris, Forbes and Fletcher $(2000: 125,128)$ indicated that the development of competence, gained through small group learning methods, such as project teams, peer exchange, individual counselling and workshops, is a more relevant focus for entrepreneurship education. These researchers also indicated that in the designing of entrepreneurship programmes the emphasis should be on the process rather than the content, with "how to" aspects being more important than "know what".

Hisrich and Peters (1998) in Henry, Hill and Leitch (2005:104) stresses that the development of particular skills, namely inner control, risk taking, innovativeness, being change oriented and persistence and visionary leadership, differentiates an entrepreneur from a manager.

Taylor, Jones and Boles (2004:230) are of the opinion that action learning is an appropriate method for responding to the problem-centred needs of would-be entrepreneurs. Action learning engenders a personal, situational and emergent process in which groups of equals are encouraged to develop a questioning and critical approach to solving their problems. These authors are of the view that the action learning approach provides a framework for dealing with complex business problems collaboratively, supportively and with an open mind. Action learning is centred around a small group of participants, or set, who are given time to discuss work-related problems with those who are facing a common adversity. Sets provide a safe environment for participants to focus on a current issue, to be inspired, discover new perspectives and formulate ideas. Each participant has the opportunity to frame a particular problem or issue, take action, reflect on that action and reframe the problem. This process encourages the developing of questioning insight (Downing, 2000:3).

Garavan and O'Cinneide (1994:5) suggest that the following are the most commonly cited objectives of entrepreneurship education and training programmes to:

1. acquire knowledge relevant to entrepreneurship,

2. acquire skills in the use of techniques in the analysis of business situations, and in the synthesis of action plans,

3. identify and stimulate entrepreneurial drive, talent and skills,

4. undo the risk-adverse bias of many analytical techniques,

5. develop empathy and support for all unique aspects of entrepreneurship,

6. devise attitudes towards change, and

7. encourage new start-ups and other entrepreneurial ventures.

Garavan and O'Cinneide (1994:9-10) also suggest according to Kolb's learning style model the learning preference of an entrepreneur. Table 1 presents a grid of learning styles and pedagogical techniques. These learning preferences should be taken into account in the education and training of entrepreneurs. 
The entrepreneur as presented in Table 1 is someone who prefers one of the active learning styles, whether that of the accommodator or converger. The findings of a number of researchers according to Garavan and O'Cinneide (1994:10) indicate that individuals who express entrepreneurial intentions exhibit psychological traits which differ from those of other individuals and are characteristic of entrepreneurs. Therefore, such individuals would be expected to have similar learning style preferences. The pedagogical methods which are best suited to an entrepreneurial learning style are those presented in quadrants III and IV of the learning grid.

Table 1: Conceptual grid of learning styles and pedagogical techniques

\begin{tabular}{|c|c|c|c|}
\hline \multicolumn{4}{|c|}{$\begin{array}{l}\text { CONCRETE EXPERIENCE } \\
\end{array}$} \\
\hline \multirow{2}{*}{ 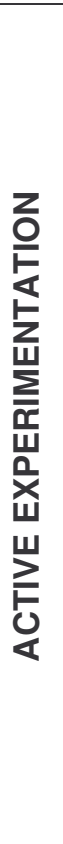 } & $\begin{array}{l}\text { Quadrant III - Active-applied } \\
\text { - } \quad \text { Changes in skills and attitudes } \\
\text { - } \quad \text { Role plays } \\
\text { - } \quad \text { Management simulation } \\
\text { - } \quad \text { Processing discussion } \\
\text { - } \quad \text {-groups/encounter groups } \\
\text { - } \quad \text { Learning diaries } \\
\text { - } \quad \text { Management of learning groups } \\
\text { - } \quad \text { Counselling }\end{array}$ & $\begin{array}{ll}\text { Quadrant II - Reflective-applied } \\
\text { - } & \text { Changes in application } \\
\text { - } & \text { Applives } \\
\text { - } & \text { Limited lecture } \\
\text { - } & \text { Cases } \\
\text { - } & \text { Role plays } \\
\text { - } & \text { Problem-oriented exams } \\
& \text { emphammed instruction with } \\
& \text { empills }\end{array}$ & \multirow{3}{*}{ 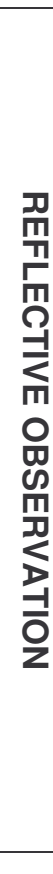 } \\
\hline & 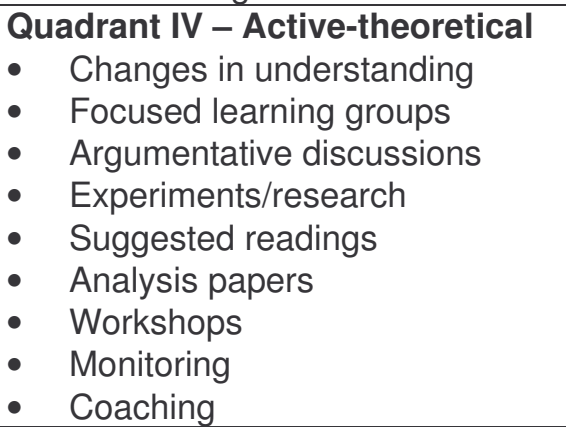 & $\begin{array}{l}\text { Quadrant I - Reflective-theoretical } \\
\text { - } \quad \text { Change in knowledge } \\
\text { - } \quad \text { Required readings } \\
\text { - } \quad \text { Handouts } \\
\text { - } \quad \text { Programmed instructions with } \\
\text { emphasis on concepts } \\
\text { - } \quad \text { Theory papers } \\
\text { Content-oriented exams }\end{array}$ & \\
\hline & & LISATION & \\
\hline
\end{tabular}

Source: Garavan and O'Cinneide (1994:10)

The learning style preference of an entrepreneur according to Kolb's learning styles (Kolb, 1984:141) corresponds with the objectives of the new outcomes-based education and training system implemented in South Africa. Curriculum 2005 propagates a more active approach, or an actionlearning approach, to incorporate not only knowledge and skill but also values, attitudes and previous experience in order to change behaviour and involve learners in their own learning (Le Roux, 2003:16).

According to Le Roux (2003:13) opportunity and the freedom to practise being entrepreneurial in a supportive climate simulating real life would help learners to become active constructors rather than passive recipients of knowledge. The strength of entrepreneurial skills, attributes and behaviours, as well as the mix of these qualities, will vary between individuals. Some individuals will be more creative, some more analytical, and some more capable of independent behaviour than others.

Gibb (1997:14) suggests in research undertaken on approaches to entrepreneurship-learning that a more flexible, in terms of location and time, as well as a more active experience-based learning approach to teaching entrepreneurs should be considered.

Heinonen and Poikkijoki (2006:85) suggest co-learning between teachers and students: the student has ownership of her or his learning and the teacher acts as a supporter and facilitator of the process, a catalyst. Experience can be organised on the basis of theory, and learning will take place as a combination of theory and experience. The task of the teacher is to develop the students' abilities to reflect on their own experience and put them in a wider context, and to give them the opportunity to make their own theoretical interpretations. 
Research studies (McClelland, 1986; Osborne, 1995; Bird, 1989; Nieuwenhuizen \& Kroon, 2002b; and Hornaday \& Aboud, 1971) have examined the personality traits associated with successful entrepreneurs. Amongst these personality traits or characteristics is a high need for achievement, independence, moderate risk taking propensity, tolerance for ambiguity, innovation, creativity and internal locus of control.

Higher education of entrepreneurs and potential entrepreneurs should follow a multidisciplinary and holistic approach that focuses on the development of those skills and abilities that were identified as success factors of entrepreneurs (Nieuwenhuizen \& Kroon, 2002b:164).

The importance of the study, the research methodology and results of the study will be now be addressed.

\section{IMPORTANCE OF THE STUDY}

This research assist curriculum developers of entrepreneurship education programmes to better align their content to the entrepreneurial skills identified by successful entrepreneurs that need to be developed, and to conduct entrepreneurship education according to the learning preferences of entrepreneurs.

\section{RESEARCH METHODOLOGY}

\section{Research Design}

This research is designed as a formal, exploratory study. The study is ex post facto because the researcher has no control over the variables - the researchers can only report on what has happened. The time dimension of the study is cross-sectional; the topical scope is statistical and the research was conducted within field conditions.

In this study a successful, established entrepreneur is defined as a major owner and manager of a business venture who is not employed elsewhere and who has been involved in the business venture for at least four years. The business venture has to be profitable and show growth over the previous three years generating an average or above average income for the entrepreneur.

\section{Population and Sample}

Non-probability purposive sampling was used because it is valuable in a study where validated instruments are used on a specific target group. The researchers relied on their experience and previous research findings to obtain units of analysis deliberately in such a manner that the sample obtained might be regarded as being representative of the relevant population (Welman \& Kruger, 2001:63). Due to the specifically defined, homogeneous nature of the group and the specialised instruments to be completed, a sample of 50 was investigated.

\section{Data Collection}

Two measurement instruments that included entrepreneurial traits and skills were identified and completed by a sample of 50 entrepreneurs of the identified population. The following were completed by each participant:

1. Biographical questionnaire

2. Schein's Career Orientations Inventory

3. Neethling's Brain Instrument (NBI)

\section{Schein's Career Inventory}

According to Schein (1985:80) a person's career anchor is his or her self-concept, consisting of self perceived talents and abilities, basic values, and the evolved sense of motives and needs as they pertain to the career. 
As a person gains occupational and life experience, his or her career anchors evolve, and once the self-concept has been formed, it becomes a stabilising force or an anchor. The anchors are the values and motives that the person will not give up if forced to make a choice. A person's awareness of his or her career anchor is raised when they have to make choices pertaining to self-development, family or career. It is valuable to become aware of these career anchors so that wise choices can be made when situations arise. Most people's self-concepts are anchored in one or more of the following career anchors:

1. autonomy/independence

2. security/stability

3. technical/functional competence

4. general management competence

5. entrepreneurial creativity

6. service or dedication to a cause

7. pure challenge

8. lifestyle

Usually one of these eight categories is a person's anchor, but most careers also permit multiple anchors. People can discover their own real values and career anchors by making use of the Career Orientations Inventory. Schein's Career Orientation Inventory is validated and does not have to be administered by a registered psychologist.

\section{Neethling's Brain Instrument (NBI)}

The brain profile theory looks at the thinking preferences or cognitive style of an individual. The first four-quadrant instrument was developed by Ned Herrmann in 1981. Herrmann's examination of Sperry's split brain studies and Paul McLean's 'Triune Brain Model' led to a combination theory, based on a metaphorical model of four quadrants (Neethling, 2003:2).

Building on the work of Herrmann and Torrance, Neethling determined that both the left and right brain processes (as originally categorised by Sperry) could be divided into two definitive categories, effectively dividing the brain into four quadrants. The Neethling Brain Instrument (NBI) divides the brain into four quadrants. The quadrants are referred to the Left 1 and Left 2 and the Right 1 and Right 2 quadrants. A person's thinking processes can be clustered into the four quadrants in the brain, with each area dealing with different thinking preferences, Hence one can deduce certain preferences in behaviour by analysing which area people prefer in their thinking.

Nobody thinks with only one quadrant. To varying degrees, we all think with our whole brain. There will, however, be a tendency for behaviour to correspond to the thinking preferences in the strongest quadrant.

In dealing with preferences, it is important to note that there are no bad or wrong profiles. The NBI is a descriptive, non-judgemental analysis, with no profile being better or worse than the other. Instead, an individual's report gives a description of his or her thinking preferences and makes recommendations based on those.

Entrepreneurship, as a career option, and creative thinking are part of the Right 1 brain quadrant (R1). Rational and analytical thinking and the evaluation of opportunities and the risk related thereto are part of the Left 1 brain quadrant (L1). The NBI is scientifically scored and validated. The instrument does not have to be administered by a registered psychologist, but rather by a registered Neethling Brain Instrument (NBI) practitioner. One of the researchers is a registered NBI practitioner.

\section{Data Analysis}

Each participant was analysed according to the NBI and Schein Career Inventory. The information was combined and used in the descriptive as well as inferential statistics.

For the data analysis the Moonstats statistical analysis programme (Welman \& Kruger, 2001: Moonstats $(D)$ was used. Descriptive statistics was used to provide a biographical analysis of 
entrepreneurs as well as their businesses. Inferential statistics were applied in the form of chi-square tests to determine inferences with regard to different categories, for example between specific brain preferences and career anchors.

\section{RESULTS}

The results consist of a biographical analysis, an analysis of Schein's Career Orientation Inventory and the Neethling Brain Instrument.

\section{Biographical Analysis}

The group of participants consisted of $76 \%$ males and $24 \%$ females. The average age of the participants is 48 years, with the youngest participant 25 years and the oldest 69 years.

The turnover of the participants varies between R264 000 and R34 million with an average turnover of R8,9 million per year.

The average number of years participants have been in their own businesses are 11.26 years with a minimum of 4 years and a maximum of 26 years.

The average number of previous businesses established by the entrepreneurs is approximately 2 with some participants having no previous businesses, and a maximum of 5 previous businesses.

The average number of full time employees employed by the participants is 27 , with 5 participants in the business with less employees, and one who employs 134 employees.

The growth of the businesses over the previous three years was up to $20 \%$ for $60 \%$ of the businesses, $16 \%$ of the businesses experienced growth of between $21 \%$ and $30 \%$ and growth for $24 \%$ of the businesses was more than $30 \%$.

According to studies undertaken by Feldman and Bolino (2000:54) older people with less education are more likely to seek self-employment than their better qualified peers as they are more vulnerable to age discrimination. This study has proved the contrary. More than $66 \%$ of the established, successful entrepreneurs have post school qualifications as opposed to only $34 \%$ who have completed their school education. 
Table 2: Characteristics of successful, established entrepreneurs. $\mathrm{N}=50$

\begin{tabular}{|c|c|c|}
\hline & CHARACTERISTICS & PERCENTAGE \\
\hline \multirow[t]{2}{*}{ Gender } & Male & $76 \%$ \\
\hline & Female & $24 \%$ \\
\hline \multirow[t]{4}{*}{ Age } & $20-30$ year & $6 \%$ \\
\hline & $31-40$ years & $30 \%$ \\
\hline & $41-50$ years & $40 \%$ \\
\hline & 51 and older & $24 \%$ \\
\hline \multirow[t]{5}{*}{ Education } & Secondary school (Matric) & $34 \%$ \\
\hline & Diploma & $10 \%$ \\
\hline & Degree & $32 \%$ \\
\hline & Postgraduate & $24 \%$ \\
\hline & Subtotal post-school qualifications & $66 \%$ \\
\hline \multirow[t]{2}{*}{ Qualifications relating to business } & Yes & $54 \%$ \\
\hline & No & $46 \%$ \\
\hline \multirow[t]{3}{*}{ Perceived risk of starting own business } & High & $60 \%$ \\
\hline & Moderate & $30 \%$ \\
\hline & Low & $10 \%$ \\
\hline \multirow[t]{6}{*}{ Number of previous businesses } & 0 & $52 \%$ \\
\hline & 1 & $16 \%$ \\
\hline & 2 & $8 \%$ \\
\hline & 3 & $14 \%$ \\
\hline & 3 & $4 \%$ \\
\hline & 5 & $6 \%$ \\
\hline \multirow[t]{3}{*}{ Years in business } & $4-10$ years & $56 \%$ \\
\hline & $11-20$ years & $28 \%$ \\
\hline & More than 20 years & $16 \%$ \\
\hline
\end{tabular}

Table 3: Characteristics of the businesses of successful, established entrepreneurs $N=50$

\begin{tabular}{|c|c|c|}
\hline & CHARACTERISTICS & PERCENTAGE \\
\hline \multirow[t]{5}{*}{ Turnover } & Less than R5 million & $52 \%$ \\
\hline & R5 million - R9,999 million & $20 \%$ \\
\hline & R10 million - R19,999 million & $10 \%$ \\
\hline & R20 million - R29,999 million & $6 \%$ \\
\hline & R30 million and more & $12 \%$ \\
\hline \multirow[t]{4}{*}{ Number of employees } & $1-10$ & $42 \%$ \\
\hline & $11-50$ & $34 \%$ \\
\hline & $51-100$ & $18 \%$ \\
\hline & More than 100 & $6 \%$ \\
\hline \multirow[t]{5}{*}{ Growth of the business over the past 3 years } & $10 \%$ or less & $40 \%$ \\
\hline & $11 \%-20 \%$ & $20 \%$ \\
\hline & $21 \%-30 \%$ & $16 \%$ \\
\hline & $31 \%-50 \%$ & $12 \%$ \\
\hline & More than $50 \%$ & $12 \%$ \\
\hline \multirow[t]{4}{*}{ Profit related to industry } & Below average & $2 \%$ \\
\hline & Average & $56 \%$ \\
\hline & Above average & $28 \%$ \\
\hline & High & $14 \%$ \\
\hline \multirow[t]{4}{*}{ Number of businesses/branches } & 1 & $54 \%$ \\
\hline & 2 & $20 \%$ \\
\hline & $3-5$ & $12 \%$ \\
\hline & More than 5 & $14 \%$ \\
\hline
\end{tabular}

\section{Results of Instruments}

First the results of the Schein Career Orientations Inventory are given, followed by the results of the Neethling Brain Instrument. 


\section{Schein's Career Orientations Inventory results}

An earlier longitudinal study undertaken by Schein (1985:55) included 44 graduates before and after they obtained their qualifications identified career anchors that are associated with various roles, namely those of the entrepreneur, the manager and the professor. The career anchor of entrepreneurs is creativity and innovation; that of the managers is competence and effectiveness; and that of professors are independence or autonomy in the control of their own time.

The results from the Schein Career Anchors Orientations Inventory of the participants are significant as they distinguish established, successful entrepreneurs from groups covered by 14 studies (Schein, 1985:57). In these studies 7,7\% of the participants had entrepreneurship anchors as opposed to the $42 \%$ of this study and $12 \%$ had autonomy anchors as opposed to $14 \%$ in this study (refer to Table 4 ). The comparative results prove that this group of participants is different from the general population and that the entrepreneurship career anchor is a distinguishing factor of successful, established entrepreneurs.

Table 4: Career anchors of successful established entrepreneurs $(\mathrm{N}=50)$

\begin{tabular}{|c|c|}
\hline CAREER ANCHOR & PERCENTAGE ENTREPRENEURS \\
\hline 1. Entrepreneurship & $42 \%$ \\
\hline 2. Autonomy & $14 \%$ \\
\hline 3. Lifestyle & $16 \%$ \\
\hline 4. Service & $6 \%$ \\
\hline 5. Challenge & $0 \%$ \\
\hline 6. Security & $12 \%$ \\
\hline 7. Managerial & $4 \%$ \\
\hline 8. Technical & $6 \%$ \\
\hline
\end{tabular}

In addition it was found that entrepreneurship is one of the three most preferred career anchors of the participants. The various career anchors are illustrated in the pie charts; the primary career anchors in Figure 1, the secondary career anchors in Figure 2 and the tertiary career anchors in Figure 3 of all participants. The Entrepreneurship career anchor is indicated by a 1 in the three Pie charts and is $42 \%, 20 \%$ and $22 \%$ respectively with a total of $84 \%$ thus indicating that $84 \%$ of the participants have Entrepreneurship as a primary, secondary or tertiary career anchor.

Figure 1: The primary career anchors of participants

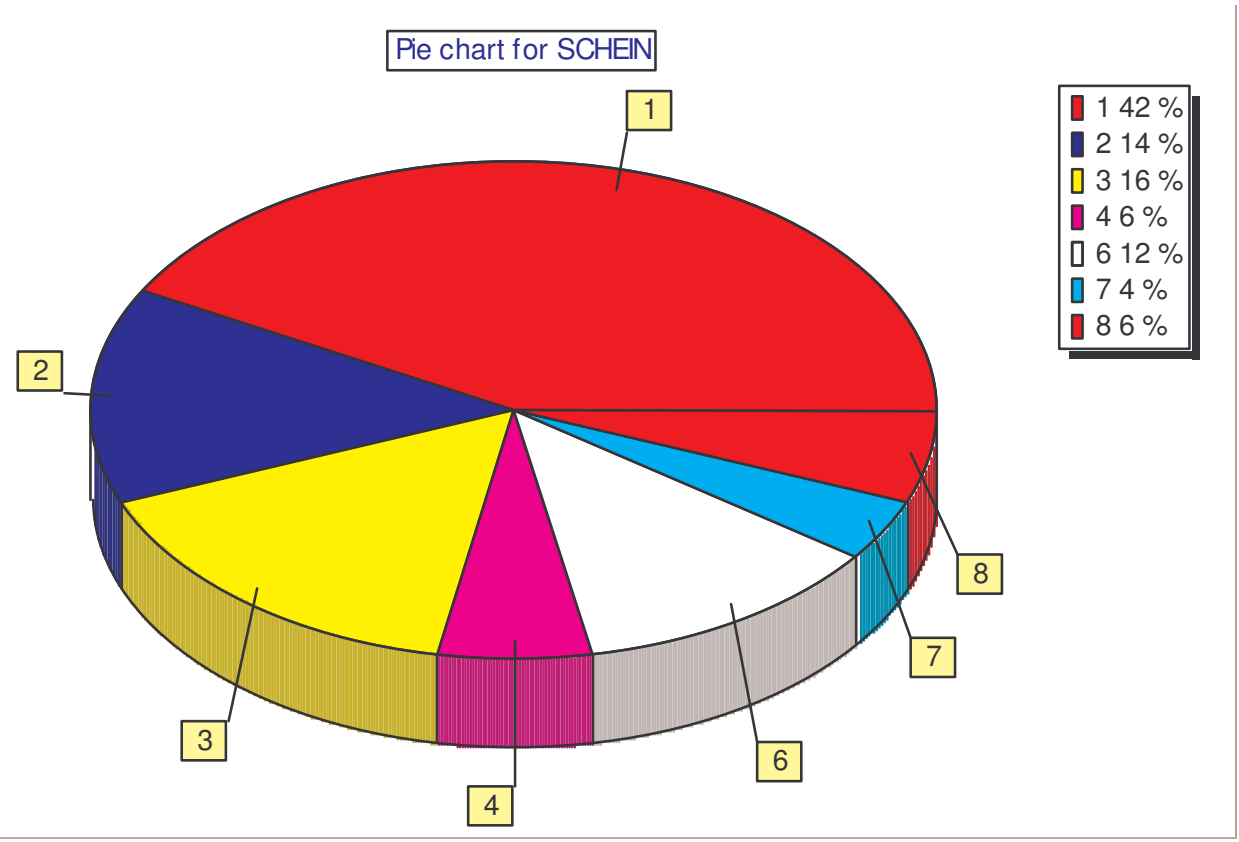


Figure 2: The secondary career anchors of participants

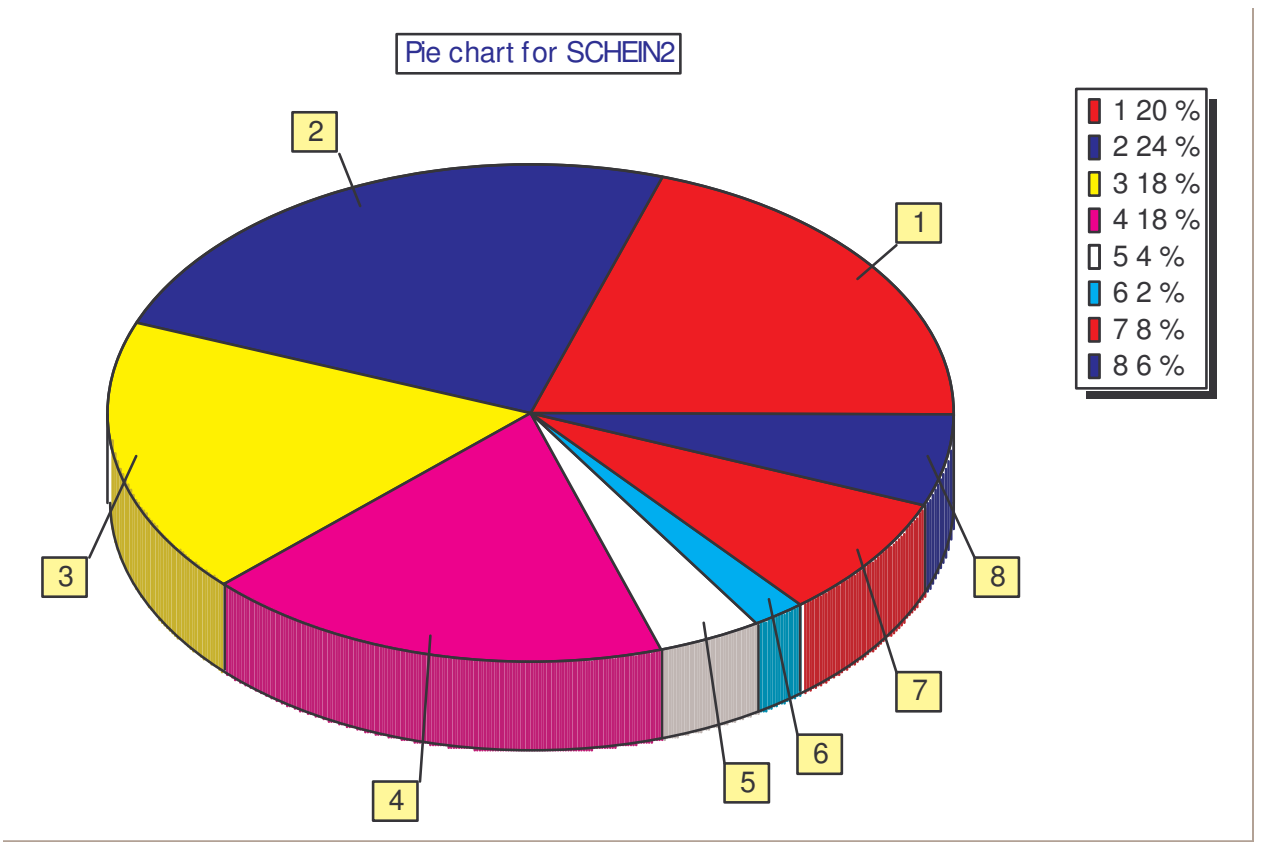

Figure 3: The tertiary career anchors of participants

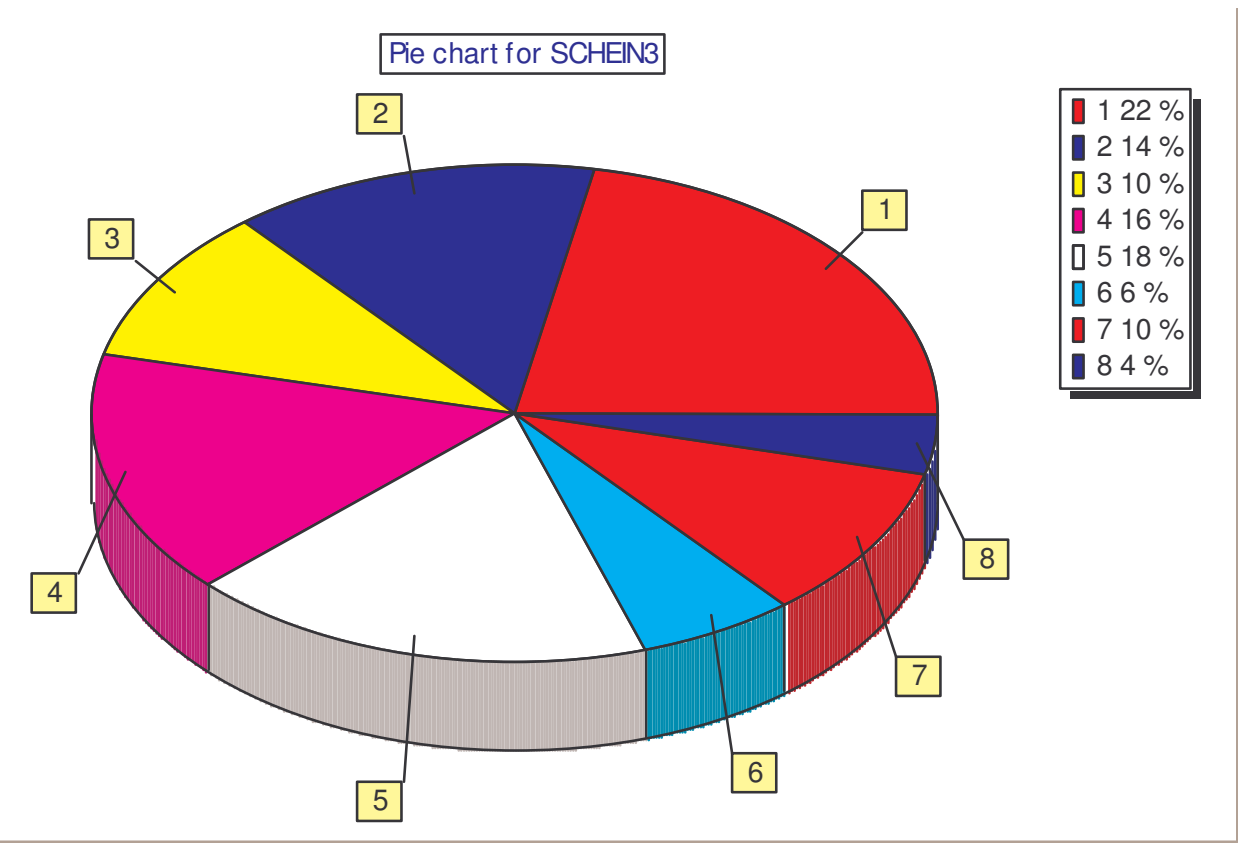

The focus of the Entrepreneurship career anchor is entrepreneurial creativity. The primary concern for someone with an entrepreneurial career anchor is to create something new, involving the motivation to overcome obstacles, the willingness to take risks, and the desire for personal prominence in whatever is accomplished. A strong need to build something and the feeling that what was built is due to personal efforts is a primary motivation. These people do not want to work for others unless they have the freedom to build their own organisation in their own way. This anchor should not be confused with either autonomy or security needs as some people start a business to be self-sufficient while entrepreneurs want to create a business and build it into extensions of themselves. 


\section{Neethling's Brain Instrument results}

If the preferences were equally distributed between the four brain quadrants, $25 \%$ would be prevalent in each quadrant.

In this study it was found that the thinking preferences of $50 \%$ of the participants are in R1. This score indicates a strong preference area. According to the Neethling's Brain Instrument, this is the quadrant in which entrepreneurship is categorised as a career choice. At $40 \%$ the L1 quadrant is the second most preferred thinking preference of successful entrepreneurs. These results are indicated in Table 4.

\section{Table 4: NBI primary brain quadrant}

Frequency table for BRAINPREF 1

\begin{tabular}{|c|c|c|c|}
\hline Value & $\mathbf{N}$ & $\%$ & Cumulative $\%$ \\
\hline $\mathbf{1 = R 1}$ & $\mathbf{2 5}$ & $\mathbf{5 0}$ & $\mathbf{5 0}$ \\
\hline $\mathbf{2}=\mathrm{R} 2$ & 3 & 6 & 56 \\
\hline $\mathbf{3 = L 1}$ & $\mathbf{2 0}$ & $\mathbf{4 0}$ & $\mathbf{9 6}$ \\
\hline $4=\mathrm{L} 2$ & 2 & 4 & 100 \\
\hline TOTAL & 50 & 100.00 & \\
\hline
\end{tabular}

The general preferences of people in the R1 quadrant are: search for alternatives, preference for the big picture, idea-intuition, strategy, synthesis, integration, risk, restlessness, becoming bored quickly, experimenting, diversity, being comfortable with chaos, fantasy, surprise and association.

Broad subject and career choices associated with the Right 1 (R1) brain quadrant are: less structured courses such as design, advertising, multi-dimensional disciplines. Business courses that include scenario creation, strategic planning, management and personal development, entrepreneurship, direct sales and marketing, pioneering new projects, generating ideas and concepts are suggested.

The teaching methods appreciated by people with a R1 or entrepreneurial preference are: holistic view, spontaneous participation, visual, associating contents with past/future, fun, experimentation and new concepts.

The learning preferences of people in the R1 quadrant are to sit or lie, they seldom sit at desks, they prefer the use of diagrams, playing learning games, trying new methods, rarely have timetables and their minds wander easily. Their environment has to be colourful with challenging information and humorous exhibitions and be artistic and changing.

The results prove that the primary thinking preference of the majority of the respondents is R1, indicating that creative thinking and entrepreneurship is a preferred career choice.

As no person is completely one-quadrant dominant, the profile indicates high, average and low preference areas.

Analysis of the secondary preference of participants proved that entrepreneurs have a combination of $\mathrm{R} 1$ and L1 as their first and second preferences. A chi-square test proved that brain preferences 1 and 2 are significantly related at the $1 \%$ level of significance indicating that a significant number of entrepreneurs have a preference for a combination of the R1 and L1 thinking. This indicates that entrepreneurs look at things holistically and strategically but they base their decisions on facts and research associated with their business ideas and planning. Table 5 show the tabulation of brain preference 1 and brain preference 2 . 
Table 5: Cross tabulation of Brain Preference 1 and Brain Preference 2

\begin{tabular}{|c|c|c|c|c|c|}
\hline \multicolumn{6}{|c|}{ BRAINPREF 1} \\
\hline & 1.00 & 2.00 & 3.00 & 4.00 & Total \\
\hline \multicolumn{6}{|c|}{ BRAINPREF 2} \\
\hline 1.00 & 0 & 1 & 5 & 0 & 6 \\
\hline 2.00 & 9 & 0 & 1 & 0 & 10 \\
\hline 3.00 & 15 & 1 & 0 & 2 & 18 \\
\hline 4.00 & 1 & 1 & 14 & 0 & 16 \\
\hline Total & 25 & 3 & 20 & 2 & 50 \\
\hline \multicolumn{6}{|c|}{ Chi-square test } \\
\hline $\begin{array}{l}\text { Chi-square } \\
p \\
d f\end{array}$ & & & & & \\
\hline
\end{tabular}

As can be seen in Table 5 the probability value $(p)$ is smaller than 0.01 , which means that there is a $99 \%$ or better probability that there is a statistically significant relationship. This means that "BRAINPREF1" (brain preference 1) and "BRAINPREF2" (brain preference 2) are statistically significantly related at the $1 \%$ level (chi-square $=46.32 ; \mathrm{df}=9 ; \mathrm{p}=0.000$ ).

The general preferences of people in the L1 quadrant are a need for accuracy; precision; exactness; a focused approach; factual reasoning; analytical thinking; objectivity; realism; concrete information; criticism; correctness; performance-driven; authoritarianism and external discipline. This is the quadrant which includes career choices such as business analysts, market researchers and people who prefer to make decisions based on research and factual information. People whose thinking preferences fall in this quadrant base their decisions on research and factual information, which is in line with the calculated risk propensity of successful entrepreneurs.

\section{IMPLICATIONS AND RECOMMENDATIONS}

Strong similarity between the Active Quadrants (III and IV) of Garavan and O'Cinneide (1994:10) quadrants and the R1 and L1 quadrants of the NBI were identified.

On the active experimentation/reflective observation dimension, the understanding of entrepreneurial behaviour indicates a primary preference for action. Opportunities and innovative ideas must be followed through to activate entrepreneurship. Thus, an entrepreneur would be expected to favour active experimentation rather than reflective observation.

On the abstract conceptualisation/concrete experience dimension, the preference of the entrepreneur is distinct. The conflict between concrete experience and abstract conceptualisation leads to creative tension. To be creative, one must be free of the constraining focus of abstract concepts in order to experience anew.

The ideal entrepreneurial-directed approach is one which requires the instructor to become a learning facilitator. Such an approach entails an extensive use of learning exercises such as role playing, management simulations, structured exercises of focused-learning feedback situations in which the participant must take an active role. The traditional "listen and take notes" role of the participant is minimised. After participating in the learning exercises, participants reflect on their experience and develop generalisations through small discussion groups. The discussion groups develop hypotheses, based on their learning experiences, which are further tested with additional learning exercises. In this way, all four learning abilities are eventually used and developed, much as they would be in the typical entrepreneurial situation.

The results of the career anchor and brain instruments correlate strongly with the findings of the studies mentioned which indicate the importance of entrepreneurial skills-training and include training in the following areas: self concept, creativity and innovation, risk orientation, good human relations, and perseverance and positive attitude. Therefore it is recommended that the following aspects needs to be included in entrepreneurial education and training: 


\section{Self Concept}

A person's way of upbringing and exposure has an influence on their career choices and on their perception of what they can and can't do. Role models and mentors built into our lives from very young, play an important role in the development of entrepreneurs. Foxcroft, Wood, Kew, Herrington and Segal (2002:22) indicate that the nature and level of formal education as well as exposure to family members or friends with entrepreneurial experience are widely believed to have a strong influence on one's own perceptions. Both these factors have a strong impact on self-perception of entrepreneurial skill. There is however, a greater scope for educators and trainers to influence the level of education of students than their personal relationships and networks. For this reason, the focus of attention should be the role of education (Foxcroft et al., 2002:22).

\section{Creativity and Innovation}

Creativity is the generation of new and useable ideas to solve any problem or use any opportunity (Amabile, 1996:36). In the long term, an enterprise's success is determined by the degree to which good ideas are generated, developed and implemented (Shaw, 1996:48). Creativity comprises people being open to new ideas and new approaches to the business and focussing on what can be done differently to ensure success in an enterprise. In other words, effective entrepreneurs take the initiative to solve problems in a unique manner.

The Left 1 quadrant drives entrepreneurs to penetrate the essence of things, and their orientation to do new and unfamiliar things (R1) makes unprecedented and original connections possible. Students should be taught to think and bring together different ideas and new approaches to existing things. For example with regard to a business idea the student has to say what makes it different from other similar businesses.

\section{Risk Orientation}

Entrepreneurs manage the risk of their enterprise by accepting control and being involved in the basic aspects of the enterprise. They control their enterprise by getting access to information. They reduce their exposure to financial loss by involving investors, often with the risk of losing control. They shorten the period between the conceptualisation of an idea and making the product or service available in the market. In this way they often limit the risk of competition. Hasty actions often also involve risk and can be harmful because the incubation period of the idea is insufficient and the time calculation poor (Bird, 1989:88).

The results of this study indicate that most of the participants regarded the risk involved in establishing their own businesses as high (57\%) with $26 \%$ regarding the risk as average and only $17 \%$ as low.

It might be difficult to teach students how to take risks. They could however be taught how to evaluate risk. This is the reason why we teach entrepreneurs how to do feasibility and viability studies. Entrepreneurs have to be taught how to do cost-benefit analyses, do cash flows and to evaluate seriously the market and the products and services of competitors. In the end entrepreneurs have to be able to take calculated risks.

\section{Good Human Relations}

Successful as well as average entrepreneurs maintain good personal relations by, for example, using influencing strategies to develop business contracts and influential people to achieve their goals. They are able to persuade people to buy a product or service or to provide financing. They also make use of their capabilities, reliability and other personal or business qualities (McClelland, 1986:227).

According to Vega (1996) in Nieman, Hough and Nieuwenhuizen (2003:16) four types of human processes that are important for successful entrepreneurship and management of people are: motivation, teambuilding, communication skills and conflict management. 
In this research study, the researcher's aim was to formulate guidelines for entrepreneurship education, determined by their learning preferences, which will focus on the development of entrepreneurs' entrepreneurial skills. The research has indicated that all the essential entrepreneurial skills are seldom addressed in entrepreneurial training. The entrepreneurial skills that need to be incorporated in these programmes are self concept, creativity and innovation, risk orientation, good human relations, perseverance and a positive attitude. This research has also revealed that entrepreneurs have different learning preferences from other students/learners. Entrepreneurs are doers and prefer to learn in an environment where they can experiment, reflect and be active in the learning process. Therefore educators need to adjust their way of teaching entrepreneurs, in order to deliver successful entrepreneurs.

\section{CONCLUSION}

Strong similarity between the Active Quadrants (III and IV) of Garavan and O'Cinneide (1994:10) quadrants and the R1 and L1 quadrants of the NBI were identified. The application of the Garavan and O'Cinneide model regarding the methodology in the education of entrepreneurs can therefore be confirmed and recommended. The ideal entrepreneurial-directed approach is one which requires the instructor to become a learning facilitator. Such an approach entails an extensive use of learning exercises such as role-playing, management simulations, structured exercises of focused-learning feedback situations in which the participant must take an active role. The results of the career anchor and brain instruments indicate the importance of entrepreneurial skills-training and include training in the following areas: self concept; creativity and innovation; risk orientation; good human relations, perseverance and positive attitude.

\section{REFERENCES}

Amabile TM. 1996. Unlimited genius. Success, 43(7):36-37.

Barrier T. 1995. The changing face of leadership. Nations Business, 83(1):41-42.

Bird BJ. 1989. Entrepreneurial Behaviour. Glenview, III, Scott, Foresman and Company.

Co M \& Mitchell B. 2006. Entrepreneurship education in South Africa: a nationwide survey. Education and Training, 48(5):348-359.

Downing S. 2000. Action learning for entrepreneurs: key issues in the design and delivery of programmes. Paper delivered at the ISBA National Small Firms Policy and Research Conference, Aberdeen Business School, Aberdeen, November.

Feldman DC \& Bolino. 2000. Career patterns of the self-employed: Career motivations and career outcomes. Journal of Small Business Management, 38(3):53-67.

Foxcroft ML, Wood E, Kew J, Herrington M \& Segal N. 2002. Global Entrepreneurship Monitor: South African Executive Report. Cape Town: Graduate School.

Garavan TN \& O'Cinneide B. 1994. Entrepreneurship Education and Training Programmes: A review and evaluation, part 1. Journal of European Industrial Training, 18(8):3-12.

Gibb AA. 1997. Small firms' training and competitiveness: building upon the small business as a learning organisation. International Small Business Journal, 15(3):13-29.

Gouws E. 1997. Entrepreneurship education: an educational perspective. South African Journal of Education, 17(3):143-149.

Harris S, Forbes T \& Fletcher M. 2000. Taught and enacted strategic approaches in young enterprises. International Journal of Entrepreneurial Behaviour and Research, 6(3):125-144.

Heinonen J \& Poikkijoki S. 2006. An entrepreneurial-directed approach to entrepreneurship education: mission impossible? Journal of Management Development, 25(1):80-94. 
Henry C, Hill C \& Leitch C. 2005. Entrepreneurship education and training: can entrepreneurship be taught? Part 1. Education and Training, 47(2):98-111.

Henry C, Hill C \& Leitch C. 2004. The effectiveness of training for new business creation. International Small Business Journal, 22(3):249-271.

Hisrich RD \& Peters MP. 1998. Entrepreneurship. $4^{\text {th }}$ ed. Boston: Irwin McGraw-Hill.

Hornaday JA \& Aboud J. 1971. Characteristics of successful entrepreneurs. Personnel Psychology, 24(2):Summer.

Ibrahim AB \& Soufani K. 2002. Entrepreneurship education and training in Canada: a critical assessment. Education and Training, 44(8/9):421-430.

Kolb DA. 1984. Experiential Learning: Experience as a source of learning and development. PrenticeHall: Englewood Cliffs.

Ladzani MW. 1999. Significance of entrepreneurship training for emerging small business enterprises in the Northern Province (Central Region). Unpublished MBA Dissertation, University of Pretoria, Pretoria.

Ladzani WM \& Van Vuuren JJ. 2002. Entrepreneurship training for emerging SMEs in South Africa. Journal of Small Business Management, 40(2):154-161.

Le Roux I. 2003. Economic and Management Science learning area of curriculum 2005 and entrepreneurial orientation. Dissertation as part of the degree of MPHIL in Entrepreneurship and Small Business Management. Pretoria: University of Pretoria.

McClelland DC. 1986. Characteristics of successful entrepreneurs. Journal of Creative Behaviour, 21(3):219-233.

Neethling and Solutions finding Neethling Brain Instruments (NBI TM). 2000. [Online] Available from: www.nbi.com [Accessed: 15/04/2003].

Nieman G. 2001. Training entrepreneurs and small business enterprises in South Africa: as situational analysis. Education and Training, 43(8/9):445-450.

Nieman GH, Hough J \& Nieuwenhuizen C (ed). 2003. Entrepreneurship: A South African Perspective. Pretoria: Van Schaik.

Nieuwenhuizen C \& Kroon J. 2002a. Creating wealth by financing small and medium enterprises of owners who possess entrepreneurial skills. Management Dynamics: contemporary research, 11(1): Summer.

Nieuwenhuizen C \& Kroon J. 2002b. Identification of entrepreneurial success factors to determine the content of entrepreneurship subjects. South African Journal of Higher Education, 16(3):157-166.

Orford J, Herrington M \& Wood E. 2004. Global Entrepreneurship Monitor South African Report. UCT Graduate School of Business: UCT Centre for Innovation and Entrepreneurship.

Osborne RL. 1995. The essence of entrepreneurial success. Management Decision, 33(7):4-9.

Owusu-Ansah W \& Fleming P. 2002. The impact of Entrepreneurship Education on Business Venturing: A Longitudinal Survey of Irish Graduates. Paper delivered at IntEnt2001 Internationalizing Entrepreneurship Education and Training Conference.91-111.

Schein EH. 1985. Career Anchors: Discovering your real values. San Diego, California: University Associates, Inc. 
Shaw D. 1996, Creativity and innovation. Business Quarterly, 61(1):48-49.

Sullivan R. (2000), Entrepreneurial learning and mentoring. International Journal of Entrepreneurial Behaviour and Research, 6(3):160 -175.

Taylor DW, Jones 0 \& Boles K. 2004. Building social capital through action learning: an insight into the entrepreneur. Education and Training, 46(5):226-235.

Vega G. 1996. When growing businesses self-destruct. Small Business Forum, 14(2):56-66.

Welman JC \& Kruger SJ. 2001, Research Methodology. Cape Town: Oxford University Press. 